\title{
Ephrin-B Reverse Signaling Is Required for Formation of Strictly Contralateral Auditory Brainstem Pathways
}

\author{
Candace Y. Hsieh, ${ }^{1 *}$ Paul A. Nakamura, ${ }^{1 *}$ Samantha 0. Luk, ${ }^{1}$ Ilona J. Miko, ${ }^{1}$ Mark Henkemeyer, ${ }^{2}$ and Karina S. Cramer ${ }^{1}$ \\ ${ }^{1}$ Department of Neurobiology and Behavior, University of California, Irvine, Irvine, California 92697, and ${ }^{2}$ Department of Developmental Biology, Kent \\ Waldrep Center for Basic Research on Nerve Growth and Regeneration, University of Texas Southwestern Medical Center, Dallas, Texas 75390-9133
}

Specificity in the projections from the mammalian ventral cochlear nucleus $(\mathrm{VCN})$ is essential for sound localization. Globular bushy cells project from the VCN to the medial nucleus of the trapezoid body (MNTB) on the contralateral, but not the ipsilateral, side of the brainstem, terminating in large synaptic endings known as calyces of Held. The precision in this pathway is critical for the computation of interaural intensity differences, which are used in sound localization. The mechanisms underlying the development of this projection are not completely understood. In this study, we tested the role of Eph receptor tyrosine kinases and their ephrin ligands in limiting the VCN-MNTB projection to the contralateral side. We found that mice with null mutations in EphB2 and EphB3 had normal contralateral VCN-MNTB projections, yet these projections also had significant numbers of aberrant collateral branches in the ipsilateral MNTB. These aberrant branches ended in calyceal terminations in MNTB. Similar ipsilateral projections were seen in mice with mutations in ephrin-B2. In both of these mouse lines, ipsilateral projections formed concurrently with normal contralateral projections and were not eliminated later in development. However, mice with mutations that affected only the intracellular domain of EphB2 had normal, strictly contralateral VCN-MNTB projections. Expression studies showed that EphB2 is expressed in VCN axons and ephrin-B2 is expressed in MNTB. Together, these data suggest that EphB2- ephrin-B2 reverse signaling is required to prevent the formation of ipsilateral VCNMNTB projections and that this signaling operates non-cell autonomously.

\section{Introduction}

The mammalian auditory brainstem requires precise neuronal connectivity to extract information used in sound localization. One key pathway computes interaural level difference (ILD), used primarily to localize high-frequency sounds (Casseday and Neff, 1973). In this pathway, axons from globular bushy cells in the ventral cochlear nucleus (VCN) project to the contralateral, but not ipsilateral, medial nucleus of the trapezoid body (MNTB) (Cant and Casseday, 1986; Glendenning et al., 1992), ending in large terminals known as calyces of Held. MNTB neurons in turn send inhibitory projections to the lateral superior olive (LSO), which also receives a tonotopically matched excitatory projection from ipsilateral VCN (Boudreau and Tsuchitani, 1968). VCN and MNTB axons converge on LSO neurons, in which relative levels of excitation versus inhibition provide the basis for the computation of ILDs (Irvine, 1986; Sanes, 1990; Tollin, 2003). The strictly contralateral projection from VCN to MNTB is thus critical to the function of the ILD circuit.

The integrity of the VCN-MNTB pathway requires specific axon pathfinding during development. $\mathrm{VCN}$ axons first grow past the ipsilateral MNTB without innervating it and then arrive

Received Jan. 22, 2010; revised May 13, 2010; accepted June 9, 2010.

This work was supported by National Institutes of Health Grants R01 DC005771, R01 EY017434, R01 MH066332, F31 DC010092, and P30 DC008369, and National Science Foundation Grant IOS-0642346. We are grateful to Dr. Leonard Kitzes and Matthew J. Korn for helpful comments on this manuscript.

${ }^{*}$ C.Y.H. and P.A.N. contributed equally to this work.

Correspondence should be addressed to Karina S. Cramer, Department of Neurobiology and Behavior, University of California, Irvine, 2205 McGaugh Hall, Irvine, CA 92697-4550. E-mail: cramerk@uci.edu.

DOI:10.1523/JNEUROSCI.0386-10.2010

Copyright $\odot 2010$ the authors $\quad 0270-6474 / 10 / 309840-10 \$ 15.00 / 0$ at the contralateral MNTB before birth in mammals (Kil et al., 1995; Hoffpauir et al., 2006). At early postnatal ages, small branches of these axons enter the contralateral MNTB (Kandler and Friauf, 1993; Kil et al., 1995) and form functional synaptic connections (Hoffpauir et al., 2006, 2009; Rodríguez-Contreras et al., 2008). However, the molecular cues underlying selective innervation of MNTB neurons by a calyx from only the contralateral VCN have not been identified.

Several families of axon guidance molecules may contribute to the specificity of the VCN-MNTB pathway. In this study, we evaluated the roles of Eph receptor tyrosine kinases and their membrane-associated ephrin ligands. These proteins mediate attractive or repulsive interactions in axon guidance and synaptic plasticity (Wilkinson, 2001; Davy and Soriano, 2005; Flanagan, 2006; Egea and Klein, 2007; Pasquale, 2008; Klein, 2009). Eph receptors include the $\mathrm{A}$ and $\mathrm{B}$ classes, which generally interact with ephrin-A and ephrin-B ligands, respectively (Lai and Ip, 2009), with a few exceptions (Gale et al., 1996; Himanen et al., 2004). Eph/ephrin signaling is bidirectional so that, during binding, signaling occurs in both the Eph-bearing cell and the ephrinbearing cell (Henkemeyer et al., 1996; Klein, 2009). Forward signaling is mediated by tyrosine kinase activity of Eph receptors, whereas reverse signaling is mediated by ephrins, with the extracellular domain of the Eph receptor acting as a ligand (Holland et al., 1996; Brückner et al., 1997).

Key roles for EphB signaling in auditory circuit development and function have been reported previously (Cramer, 2005; Cramer et al., 2006; Miko et al., 2007, 2008). Here, we have examined the projections from VCN to MNTB in mice with mutant 
EphB proteins. Our results suggest that mutations resulting in impaired reverse signaling are associated with significant numbers of abnormal projections from VCN to ipsilateral MNTB. These findings suggest that ephrin-B reverse signaling normally restricts VCN axons to contralateral MNTB.

\section{Materials and Methods}

Animals

In this study we used $E p h B 2^{\text {null }} ; E p h B 3^{\text {null }}, E p h B 2^{\text {lacZ }} ; E p h B 3^{\text {null }}$, and ephrin-B2 ${ }^{\text {lacZ }}$ transgenic mouse lines on a CD-1/129 background and wild-type CD-1 mice. Animals $(n=196)$ were studied at ages postnatal day 0 (P0) to P28. The EphB2 ${ }^{\text {null }} ; E p h B 3^{\text {null }}$ and $E p h B 2^{\text {lacZ }} ; E p h B 3^{\text {null }}$ mice differ in the mutant alleles of the EphB2 gene (Cowan et al., 2000). Both mouse lines have a null mutation in EphB3. Whereas the EphB2 ${ }^{\text {null }}$ allele lacks the EphB2 protein, the EphB2 ${ }^{\text {lacZ }}$ mutant allele encodes a fusion protein containing the extracellular, transmembrane, and juxtamembrane domains of EphB2 with $\beta$-galactosidase replacing the intracellular domain. The mutant protein permits reverse but not forward signaling. In ephrin-B2 ${ }^{\text {lacZ }}$ mice (Dravis et al., 2004), the mutant allele encodes a membrane-bound ephrin-B2- $\beta$-galactosidase fusion protein that lacks the cytoplasmic domain and permits forward but not reverse signaling. Only ephrin-B2 $2^{\text {lacZ/+ }}$ and ephrin-B2 $2^{+/+}$mice were used in this study, because the ephrin-B2 $2^{\text {lacZ/lacZ }}$ mutation is lethal on or before P0. For the $E p h B 2^{\text {null }} ; E p h B 3^{\text {null }}$ and $E p h B 2^{\text {lacZ }} ; E p h B 3^{\text {null }}$ mouse lines, we used mice that were homozygous mutant, heterozygous, or wild type for the EphB2 gene and homozygous mutant for EphB3. All procedures were approved by the University of California, Irvine, Institutional Animal Care and Use Committee.

For PCR genotyping, mice were anesthetized using isoflurane and DNA was extracted from tail samples with $100 \%$ isopropanol after an intervening lysis step. DNA was then resuspended in 50-100 $\mu \mathrm{l}$ of sterile water and stored at $4^{\circ} \mathrm{C}$. The PCR reaction was performed in a total volume of $15 \mu \mathrm{l}[100 \mathrm{mg} / \mu \mathrm{l} \mathrm{DNA}, 20 \mu \mathrm{M}$ of each primer, $1 \mathrm{~mm}$ PCR Nucleotide Mix (Roche), and $1 \mathrm{U} / \mu \mathrm{l}$ Taq polymerase (Promega) with the appropriate reaction buffer] and was performed on DNA from each animal. A positive control (a known heterozygote) and negative control (PCR mix without DNA) were included in every gel. The following primers were used for PCR.

EphB2;EphB3 mutant mice (Henkemeyer et al., 1996). The genotype in the $E p h B 2^{\text {null }} ; E p h B 3^{\text {null }}$ mouse line was determined using three primers: N1 PCR A, 5' -ACG ATT GCC TAG GCT CTT GGA GTA G-3'; N1 PCR B, 5'-GGG TAC ATC TCA GTG GTA GAA TG-3'; and Neo3' PCR, 5'-GTC AGT TTC ATA GCC TGA AGA ACG-3'. Gel electrophoresis yielded a wild-type PCR product of $600 \mathrm{bp}$ and an EphB2 ${ }^{\text {null }}$ mutant product of $270 \mathrm{bp}$.

The $E p h B 2^{\text {lacZ }} ; E p h B 3^{\text {null }}$ mouse line was genotyped using three different primers: N2 PCR 1, $5^{\prime}$-CAC AAG TCA TTT TTG CCA CTC TAG-3'; N2 PCR 2, 5' -TAA AAC GAC GGG ATC ATC GCG AGC C-3'; and N2 PCR 6, 5' -AGC CAT GGT ACC TTG AGG CAT TTG-3'. The wild-type product is $450 \mathrm{bp}$, and the $\mathrm{EphB} 2^{\text {lacZ }}$ mutant product is $400 \mathrm{bp}$.

The presence of the EphB3 ${ }^{\text {null }}$ mutation was determined using two separate PCR reactions, one wild-type reaction and one mutant reaction. The wild-type reaction uses two primers: Sek 4 44, 5' -CCA GCA ACG CCG TGT GAC CTG TG-3' ; and Sek4 45, 5' -ACC AGG GAG CTG GTC TAG GTG GG- $3^{\prime}$. The product is $800 \mathrm{bp}$. The mutant reaction uses two primers: Sek4 43, 5'-GCT CCC GAT TCG CAG CGC ATC G-3'; and Sek4 44, same primer used for wild-type reaction. The product is $550 \mathrm{bp}$.

Ephrin-B2 ${ }^{\text {lacZ }}$ mice (Dravis et al., 2004). Three oligonucleotides (LZ, EB2-1, and EB2-2N) containing the sequences AGGCGATTAAGTTGGGTAACG, TCTGTCAAGTTCGCTCTGAGG, and CTTGTAGTAAATGTTGGCAGGACT were used (Operon Biotechnologies). Gel electrophoresis of PCR product revealed a $500 \mathrm{bp}$ band for wild-type ephrin-B2 allele and a $400 \mathrm{bp}$ band for the ephrin-B2 ${ }^{\text {lacZ }}$ allele.

\section{EphB2 and ephrin-B2 immunohistochemistry}

For EphB2 immunohistochemistry, the primary antibody (Zymed/Invitrogen) was a rabbit polyclonal antiserum generated against a synthetic peptide derived from the juxtamembrane region of the mouse EphB2 protein, used at $5 \mu \mathrm{g} / \mathrm{ml}$. For ephrin-B2 immunohistochemistry, the primary antibody (Neuromics) was a goat polyclonal antiserum generated against the extracellular domain of the mouse ephrin-B2 protein, used at $10 \mu \mathrm{g} / \mathrm{ml}$. Wild-type mice were perfused with $4 \%$ paraformaldehyde (PFA), and brainstem tissue was sectioned coronally at $16 \mu \mathrm{m}$ on a cryostat (Leica Microsystems). Slides were immersed in $0.03 \% \mathrm{H}_{2} \mathrm{O}_{2}$ in methanol, rinsed in TBST $(0.05 \%$ Triton X-100 in $0.1 \mathrm{M}$ Tris-buffered saline, $\mathrm{pH}$ 7.4), and incubated in blocking solution containing TBST with $3 \%$ normal goat serum (for EphB2) or normal rabbit serum (for ephrinB2). Slides were then incubated overnight in primary antibody in $1 \%$ serum in TBST, rinsed, incubated with a biotinylated anti-rabbit or antigoat secondary antibody (for EphB2 and ephrin-B2, respectively; Vector Laboratories) diluted in $1 \%$ serum in TBST, rinsed, and incubated in $\mathrm{ABC}$ solution (Vector Laboratories). Slides were reacted with 3,3'diaminobenzidine (DAB), and dehydrated in a graded series of ethanol to xylene, and coverslipped with DPX. To facilitate identification of anatomical borders of brainstem nuclei, thionin staining was performed on every third section. Negative control sections were processed with the above protocol except that the primary antibody was omitted.

To assess whether expression varied with the frequency axis of MNTB, the optical density (OD) was measured in immunolabeled sections from P4 and P12 wild-type mice using NIH ImageJ. MNTB was divided into five equal parts, and OD was measured in each of those divisions, encompassing the full mediolateral extent of each MNTB. Values were normalized to the background level for each section. Linear regression analysis was used to test whether OD varied systematically along the mediolateral axis.

\section{Stereology}

The cell density and volume of MNTB were measured in thionin-stained sections from P12 wild-type and ephrin-B2 ${ }^{\text {lacZ/+ }}$ mice. To measure cell density, boxes with fixed size were placed in rostral and caudal sections of MNTB, and the number of nuclei within each box was counted for each section. Measurements from sections were then averaged together to obtain a single value for each animal. The Cavalieri method was used to obtain MNTB volume estimates. Briefly, MNTB area was measured using Openlab software (Improvision) in alternate sections. MNTB area measurements were summed, multiplied by 2 (the section spacing), and multiplied by the section thickness $(50 \mu \mathrm{m})$ to obtain an MNTB volume for each animal. $t$ tests were used to determine whether cell density and volume differed significantly between genotypes.

\section{Neuroanatomical labeling}

To visualize the projections from VCN to MNTB, axons from VCN were labeled in two ways: with lipophilic dyes in fixed tissue or with dextran dyes in fresh tissue slices made in an acute in vitro preparation. In fixed tissue, we used the lipophilic dye NeuroVue Red (PTI Research), as described previously (Hsieh and Cramer, 2006; Hsieh et al., 2007). After perfusion with $4 \%$ PFA, the cerebellum was carefully dissected away so that VCN was clearly visible. With fine forceps, a small piece of NeuroVue Red filter paper $\left(100-200 \mu \mathrm{m}^{2}\right)$ was placed in VCN. To allow dye transport, brainstems were incubated in $4 \%$ PFA at $37^{\circ} \mathrm{C}$ for $10-14 \mathrm{~d}$. Coronal vibratome sections were then cut at $100 \mu \mathrm{m}$, mounted onto slides, and coverslipped with Glycergel mounting medium (Dako).

In fresh tissue, we used dextran dyes in acute brainstem slices maintained in vitro. First, mice were killed with an overdose of isoflurane and perfused transcardially with artificial CSF (ACSF) (130 mм NaCl, $3 \mathrm{~mm}$ $\mathrm{KCl}, 1.2 \mathrm{~mm} \mathrm{KH}_{2} \mathrm{PO}_{4}, 2.4 \mathrm{~mm} \mathrm{CaCl}_{2}, 1.3 \mathrm{~mm} \mathrm{MgSO}_{4}, 20 \mathrm{~mm} \mathrm{NaHCO}_{3}, 3$ mM HEPES, and $10 \mathrm{~mm}$ glucose saturated with $\left.95 \% \mathrm{O}_{2} / 5 \% \mathrm{CO}_{2}\right)$. Brainstems were quickly removed, and thick brainstem slices $(0.5-1.0 \mathrm{~mm})$ were cut and maintained in oxygenated ACSF. Dextran amine dyes (rhodamine or Alexa Fluor 488, 3000 molecular weight; Invitrogen) were used in a $6.25 \%$ solution containing $0.4 \%$ Triton X-100 in PBS. Brainstems were injected either unilaterally with a single dye or bilaterally with two different dyes. Dye solutions were delivered to VCN using pressure injection through a pulled micropipette attached to a Picospritzer. Current was subsequently applied at the dye injection site. Dye was allowed to transport for $1-3 \mathrm{~h}$. Tissue was fixed overnight in $4 \%$ PFA in PBS at 
$4^{\circ} \mathrm{C}$, rinsed, then sectioned on a vibratome at $100 \mu \mathrm{m}$, mounted on slides, and coverslipped with Glycergel mounting medium.

In some cases, we delivered small deposits of rhodamine dextran amine (RDA) or horseradish peroxidase (HRP) to label small numbers of identifiable individual axons in P6-P28 ephrin-B2 $2^{\text {lacZ/+ }}$ mice. Using a pulled glass pipette coated with concentrated RDA or HRP, three to four deposits were made in the ventral acoustic stria, just ventromedial to the VCN. Dye was allowed to transport for $2 \mathrm{~h}$, and brainstems were fixed in $4 \%$ PFA at $4^{\circ} \mathrm{C}$ overnight. Brainstems were sectioned coronally at $150-200 \mu \mathrm{m}$ on a vibratome, reacted for DAB (for HRP deposits), mounted on slides, and coverslipped.

\section{VCN axon tracing and synaptic marker immunofluorescence}

To test whether aberrant terminations expressed synaptic markers, we used in vitro dye labeling with RDA in the fresh tissue slice preparation described above, combined with immunolabeling of synaptic terminal proteins. RDA was applied unilaterally in brainstems obtained from P3-P4, P9-P10, and P25-P26 mice. Brainstems were then fixed overnight in $4 \%$ PFA at $4^{\circ} \mathrm{C}$ and were sectioned at $50 \mu \mathrm{m}$ on a microtome or $25 \mu \mathrm{m}$ on a cryostat (P3-P4). Tissue sections containing MNTB were then processed for synapsin I or SV2 immunofluorescence. Sections were incubated in blocking solution containing $4 \%$ normal goat serum and $0.5 \%$ Triton X-100 in PBS for $1 \mathrm{~h}$ at room temperature. We used primary antibody generated against the presynaptic protein synapsin I (Abcam) or SV2. The SV2 antibody developed by Kathleen M. Buckley (Harvard Medical School, Boston, MA) was obtained from the Developmental Studies Hybridoma Bank developed under the auspices of the National Institute of Child Health and Human Development and maintained by the University of Iowa (Department of Biology, Iowa City, IA). Primary antibodies were used at $0.2 \mu \mathrm{g} / \mathrm{ml}$ (synapsin I) or $1 \mu \mathrm{g} / \mathrm{ml}$ (SV2) in blocking solution, and tissue was incubated at $4^{\circ} \mathrm{C}$ overnight. Sections were rinsed with blocking solution and then incubated in a secondary antibody solution containing either goat anti-rabbit Alexa Fluor 488 (for synapsin I reactivity) or goat antimouse Alexa Fluor 405 or 488 (for SV2 reactivity) diluted at $2 \mu \mathrm{g} / \mathrm{ml}$ in blocking solution for $2 \mathrm{~h}$ at room temperature. Sections were rinsed, mounted on slides, coverslipped, and imaged.

\section{Imaging}

Images of brainstem tissue were obtained with either a Carl Zeiss Axiocam digital camera operated with Openlab software (Improvision) or a custom-made video-rate two-photon laser scanning microscope, as described previously (Nguyen et al., 2001; Stutzmann et al., 2003; Stutzmann and Parker, 2005). Briefly, excitation was provided by trains of 100 fs pulses at 750-800 $\mathrm{nm}$ from a Chameleon titanium:sapphire laser (Coherent). The laser beam was scanned at 30 frames per second and focused through a $20 \times$ water-immersion objective [numerical aperture (NA) 0.95] or $40 \times$ oil-immersion objective (NA 1.3) on an upright microscope (Olympus BX51WIF; Olympus America). Emitted fluorescence light was detected by photomultipliers (Hamamatsu) to derive a video signal that was captured and analyzed using SlideBook 5.0 (Intelligent Imaging Innovations). $Z$-stacks were acquired at $0.5-1.0 \mu \mathrm{m} /$ plane, rendered in three dimensions, and exported as TIFF files for additional
EphB2
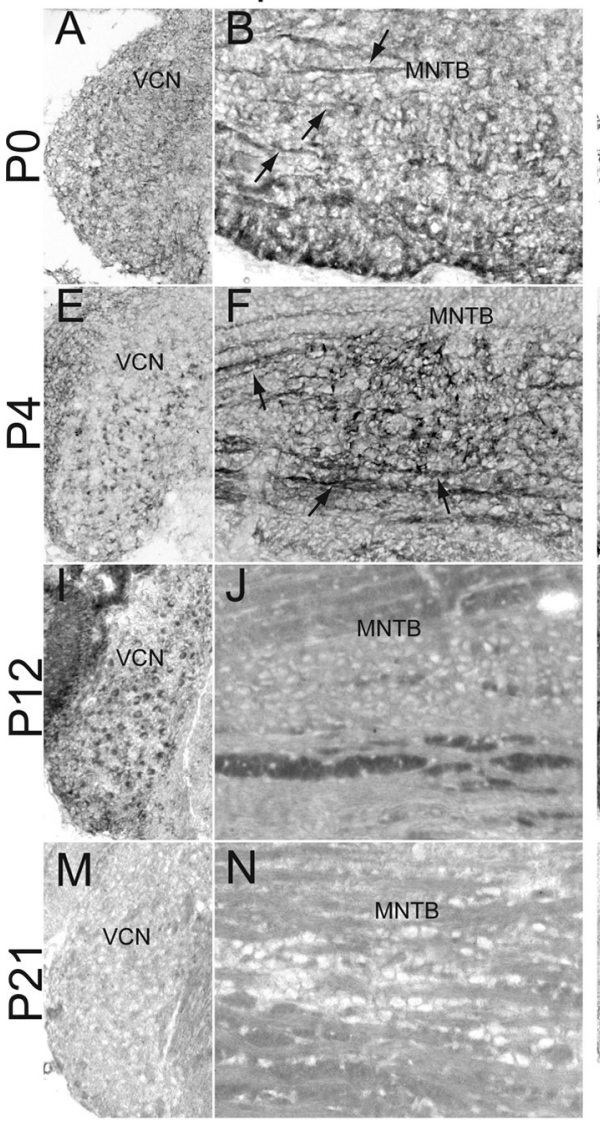

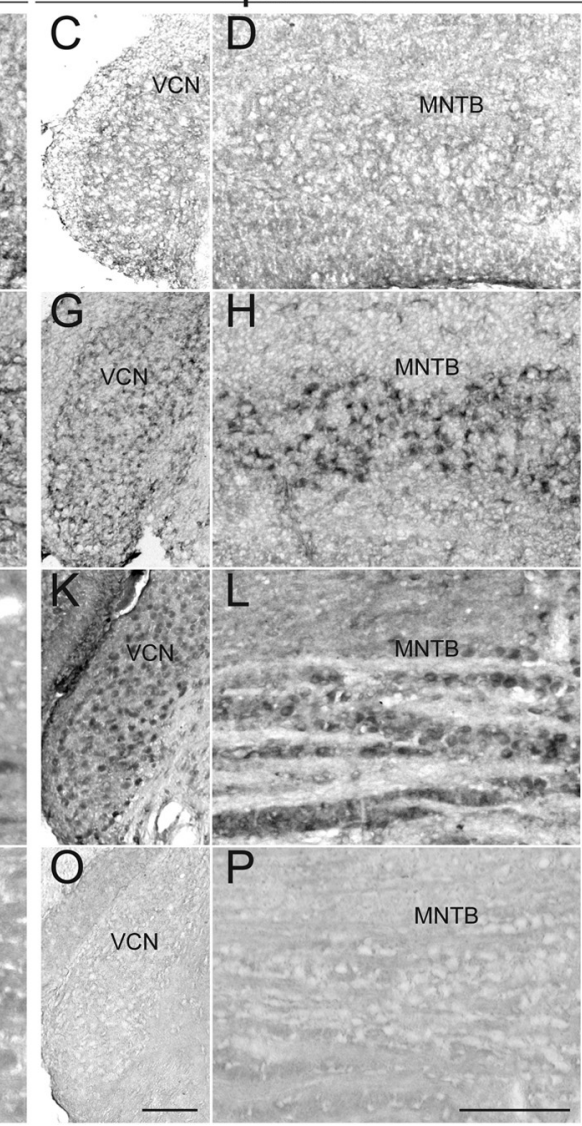

ephrin-B2
Figure 1. Expression of EphB2 and ephrin-B2 during postnatal development. At PO: $A$, EphB2 is lightly and evenly expressed roughout VCN. $B$, EphB2 is also expressed in VCN projection axons (arrows) in the brainstem near MNTB. C, Ephrin-B2 expression than at PO. $\boldsymbol{F}$, EphB2 expression in VCN axons (arrows) and VCN axon terminals is stronger than at PO. G, Ephrin-B2 shows a more punctate expression pattern than at $\mathrm{PO} . \boldsymbol{H}$, Ephrin-B2 expression appears to be perisomatic in MNTB. At P12:I, EphB2 expression in $\boldsymbol{N}$, There is a lack of EphB2 staining in VCN axons in the brainstem. $\mathbf{O}$, There is a lack of ephrin-B2 staining in VCN. $\boldsymbol{P}$, There is no apparent ephrin-B2 staining in MNTB. Scale bars: $\mathbf{O}$ (for $\boldsymbol{A}, \boldsymbol{C}, \boldsymbol{E}, \boldsymbol{G}, \boldsymbol{I}, \boldsymbol{K}, \boldsymbol{M}, \mathbf{O}), \boldsymbol{P}$ (for $\boldsymbol{B}, \boldsymbol{D}, \boldsymbol{F}, \boldsymbol{H}, \boldsymbol{J}, \boldsymbol{L}, \boldsymbol{N}, \boldsymbol{P}), 100 \mu \mathrm{m}$.

analysis. Images obtained with either microscope were then prepared for figure layout with Adobe CS4 software (Adobe Systems).

\section{Data analysis}

For each mouse genotype, we evaluated whether the VCN-MNTB projection was restricted to the contralateral MNTB. To enable comparisons between mouse lines, we corrected for variations in the size of dye placement or volume of dextran dye injections as described previously (Hsieh and Cramer, 2006; Hsieh et al., 2007). Specifically, for all sections from each mouse, we counted dye-labeled calyceal terminations in the MNTB ipsilateral to the dye placement (MNTBi) and divided that count by the total number of calyceal terminations in the MNTB contralateral to the dye placement $(\mathrm{MNTBC})$. This ratio, the $\mathrm{I} / \mathrm{C}$ ratio, was calculated for each animal and sorted by genotype. To determine differences in the I/C ratio between different mouse genotypes, we used a Wilcoxon/Kruskal-Wallis rank-sum test.

\section{Results}

\section{EphB2 and ephrin-B2 expression in developing} auditory brainstem

To determine the roles of EphB2 and ephrin-B2 in the development of the VCN-MNTB pathway, we first surveyed the expression of these proteins in wild-type brainstems at ages P0-P21. Immunohistochemical labeling over this range of ages revealed complementary expression patterns. At P0, EphB2 was lightly 

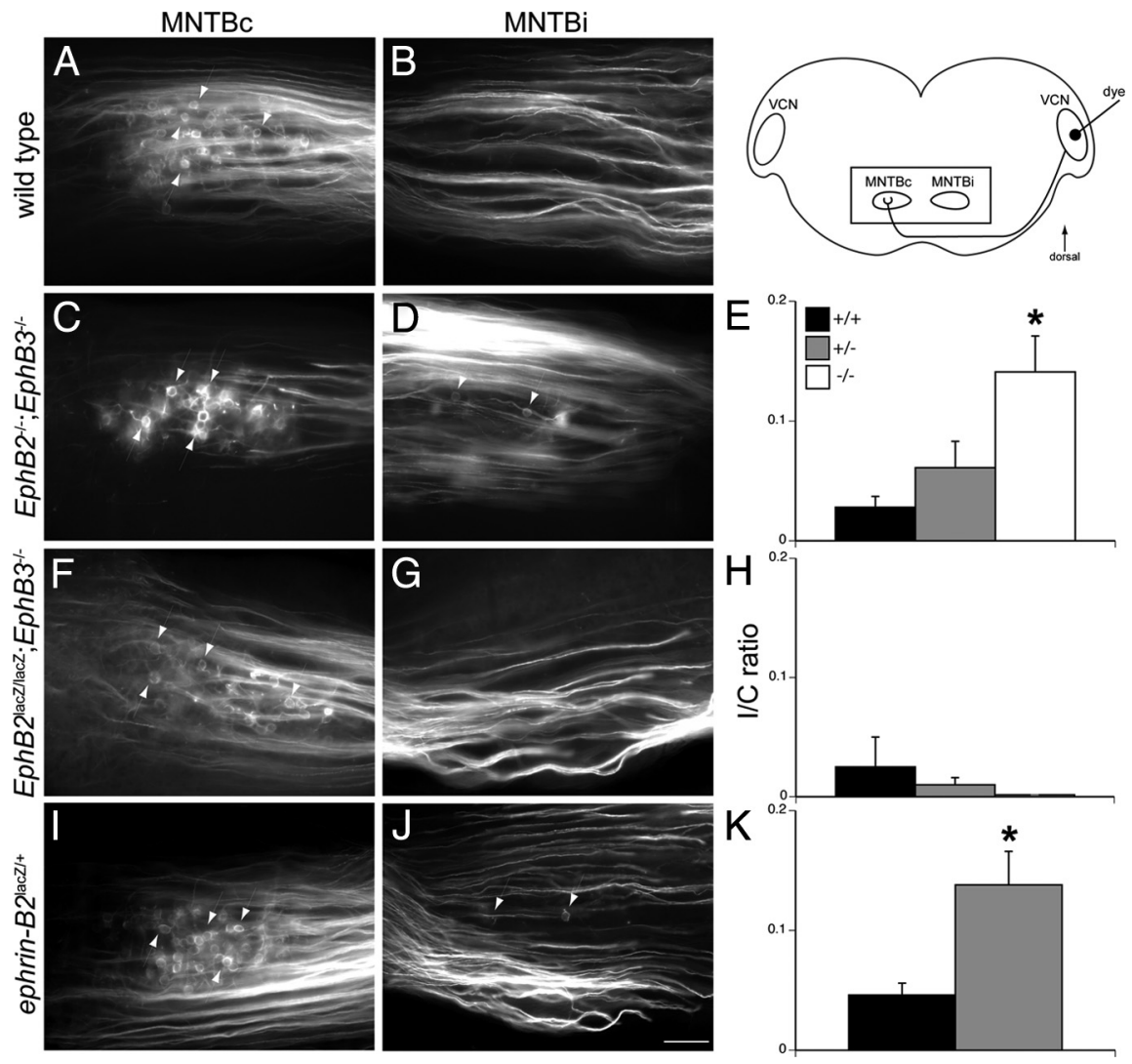

Figure 2. Effects of EphB2, EphB3, and ephrin-B2 mutations on axonal projections from VCN to MNTB. The schematic diagram shows the orientation of brainstem sections and dye labeling protocol. For all panels, dye originates on the right side of the image, in the VCN outside the field of view. The rectangle indicates the portion of the section in which labeling will be evaluated. Labeling in fixed tissue was performed at P10 -P14 in wild-type and transgenic mice. $\boldsymbol{A}$, In wild-type mice, dye labeling of VCN results in labeled calyces in MNTBc. Arrows indicate some of the labeled calyceal terminations. $\boldsymbol{B}$, No aberrant projections are seen in MNTBi. C, In EphB2 $2^{-1-} ; \mathrm{EphB3}^{-/-}$mice, VCN-MNTBc projections are normal and terminate in identifiable calyces (arrows). D, However, there are also abnormal VCN projections to MNTBi that terminate in calyx-like morphology (arrows). $\boldsymbol{E}$, A ratio of the number of ipsilateral calyces to the number of contralateral calyces (I/C ratio) reveals that EphB2 ${ }^{-1-} ; E p h B 3^{-/-}$mice have significantly more aberrant projections $\left(^{*}\right)$ than $E p h B 2^{+/+} ; E p h B 3^{-/-}$orEphB2 ${ }^{+/-} ; E p h B 3^{-/-}$mice. $F_{\text {, In EphB2 }}{ }^{\text {lacz/lacz. }}$;EphB3 ${ }^{-/-}$mice, VCN-MNTBc projections are normal and terminate in identifiable calyces (arrows). G, No aberrant projections are seen in MNTBi. $\boldsymbol{H}$, There are no significant differences in $\mathrm{I} / \mathrm{C}$ ratios for $E p h B 2^{+/+} ; E p h B 3^{-/-}, E p h B 2^{\text {lacZ/+}} ; E p h B 3^{-/-}$, and EphB2 ${ }^{\text {lacZ/lacZ. }}$; $E p h B 3^{-/-}$mice. I, In ephrin-B2 lacZI+ mice, VCN-MNTBC projections appear normal and terminate in identifiable calyces (arrows). $\boldsymbol{J}$, However, there are aberrant projections from VCN to MNTBi (arrows). $\boldsymbol{K}, \mathrm{I} / \mathrm{C}$ ratios reveal significantly more aberrant projections $\left(^{*}\right)$ in ephrin-B2 ${ }^{\text {lacZ/+}}$ than ephrin-B2 $2^{+/+}$mice. ${ }^{*} p<0.05$. Scale bar (in $\left.\boldsymbol{J}\right): \boldsymbol{A}-\boldsymbol{D}, \boldsymbol{F}, \mathbf{G}, \boldsymbol{I}, \boldsymbol{J}, 50 \mu \mathrm{m}$.

expressed in VCN and VCN axons (Fig. 1A,B). Ephrin-B2 expression was not seen in VCN and MNTB at P0 (Fig. 1C,D). At P4, EphB2 expression increased in VCN neurons (Fig. $1 E$ ) and VCN axons (Fig. $1 F$ ). Ephrin-B2 expression was observed in VCN and MNTB cell bodies at this age (Fig. $1 G, H$ ). At P12, EphB2 and ephrin-B2 expression in VCN remained heavy (Fig. $1 I, K$, respectively), whereas EphB2 VCN axon staining substantially diminished (Fig. $1 \mathrm{~J}$ ). Expression of ephrin-B2 in MNTB was still apparent at P12 (Fig. IL). At P21, expression of EphB2 and ephrin-B2 in VCN and MNTB was undetectable (Fig $1 M-P$ ). Together, these results indicate that EphB2 is expressed in VCN axons and ephrin-B2 is expressed in MNTB neurons in the VCNMNTB pathway at early postnatal ages, with a peak in expression at approximately $\mathrm{P} 12$ and a decline thereafter.

These expression studies showed that ephrin-B2, but not EphB2, is expressed in MNTB during development. Because Eph proteins in many cases have graded expression that facilitates the formation of topographic projections (McLaughlin and O'Leary, 2005; Flanagan, 2006), we examined the expression of ephrin-B2 along the tonotopic (mediolateral) axis of MNTB. OD measurements were made in ephrin-B2 immunolabeled MNTB from P4 and P12 wild-type mice. These measurements were made from sequential binned regions across the mediolateral extent of MNTB at both ages. Linear regression analysis showed that optical density did not vary with mediolateral position in MNTB at P4 $\left(r^{2}=0.019, p>0.5 ; n=3\right.$ animals $)$ or at P12 $\left(r^{2}=0.015, p>0.5\right.$; $n=4$ ) (supplemental Fig. 1, available at www.jneurosci.org as supplemental material).

\section{Effects of EphB2, EphB3, and ephrin-B2 mutations}

To determine the roles of EphB2, EphB3, and ephrin-B2 in the development of strictly contralateral brainstem projections, we examined brainstem projections at $\mathrm{P} 10-\mathrm{P} 14$, just before a time when sound-evoked responses have adult-like properties (Sonntag et al., 2009) and the VCN-MNTB projection is nearly mature (Kandler and Friauf, 1993; Kil et al., 1995; Ford et al., 2009). We unilaterally labeled $\mathrm{VCN}$ in mice from the $E p h B 2^{\text {null, }}$ $E p h B 3^{\text {null }}, E p h B 2^{\text {lacZ }} ; E p h B 3^{\text {null }}$, and ephrin$B 2^{\text {lacZ }}$ mouse lines using NeuroVue Red dye placement in fixed tissue and then evaluated labeled terminations in MNTBC and MNTBi (see schematic diagram in Fig. 2). We counted labeled calyces in MNTBi and MNTBc and obtained an I/C ratio (see Materials and Methods) that normalizes for interanimal variations in the amount of dye delivered to VCN and thus allows for comparisons between animal groups.

In wild-type animals, $\mathrm{VCN}$ projections terminated in identifiable calyces in MNTBc (Fig. 2A) but not MNTBi (Fig. $2 B$ ), yielding a very low $\mathrm{I} / \mathrm{C}$ ratio of $0.046 \pm 0.010$ ( $n=16$ animals $)$. Similarly, we found that, in $E \mathrm{phB2} 2^{+/+} ; \mathrm{EphB3^{-/- }}$ mice, VCN projections terminated only in $\mathrm{MNTBc}$, yielding an I/C ratio of $0.0281 \pm 0.09$ $(n=9$; data not shown). A Wilcoxon/Kruskal-Wallis test revealed no significant difference between wild-type mice and these mice with only null mutations of EphB3 ( $p=0.27)$. However, in $E p h B 2^{+/-} ; E p h B 3^{-1-}$ and $E p h B 2^{-1-} ; E p h B 3^{-1-}$ mice, there were clearly visible abnormal projections from VCN to MNTBi (Fig. $2 D$ ) in addition to a normal, robust projection from $\mathrm{VCN}$ to MNTBc (Fig. 2C). These ipsilateral projections terminated in structures that morphologically resembled the calyx of Held. I/C ratios for these groups were $0.061 \pm 0.022(n=12)$ and $0.141 \pm$ $0.030(n=5)$, respectively (Fig. $2 E$ ), indicating that the abnormal ipsilateral projection amounted to $\sim 10 \%$ of the contralateral projection. I/C ratios for $E p h B 2^{-1-} ; E p h B 3^{-1-}$ mice were significantly higher than $E p h B 2^{+/+} ; E p h B 3^{-/-}$mice $(p<0.014)$. These data suggest that EphB2, alone or together with EphB3, is required to prevent formation of ipsilateral VCN-MNTB projections.

We assessed brainstem projections in mice from the $E p h B 2^{\text {lacZ }} ; E p h B 3^{\text {null }}$ line (Fig. $2 F-H$ ). We found that all three 

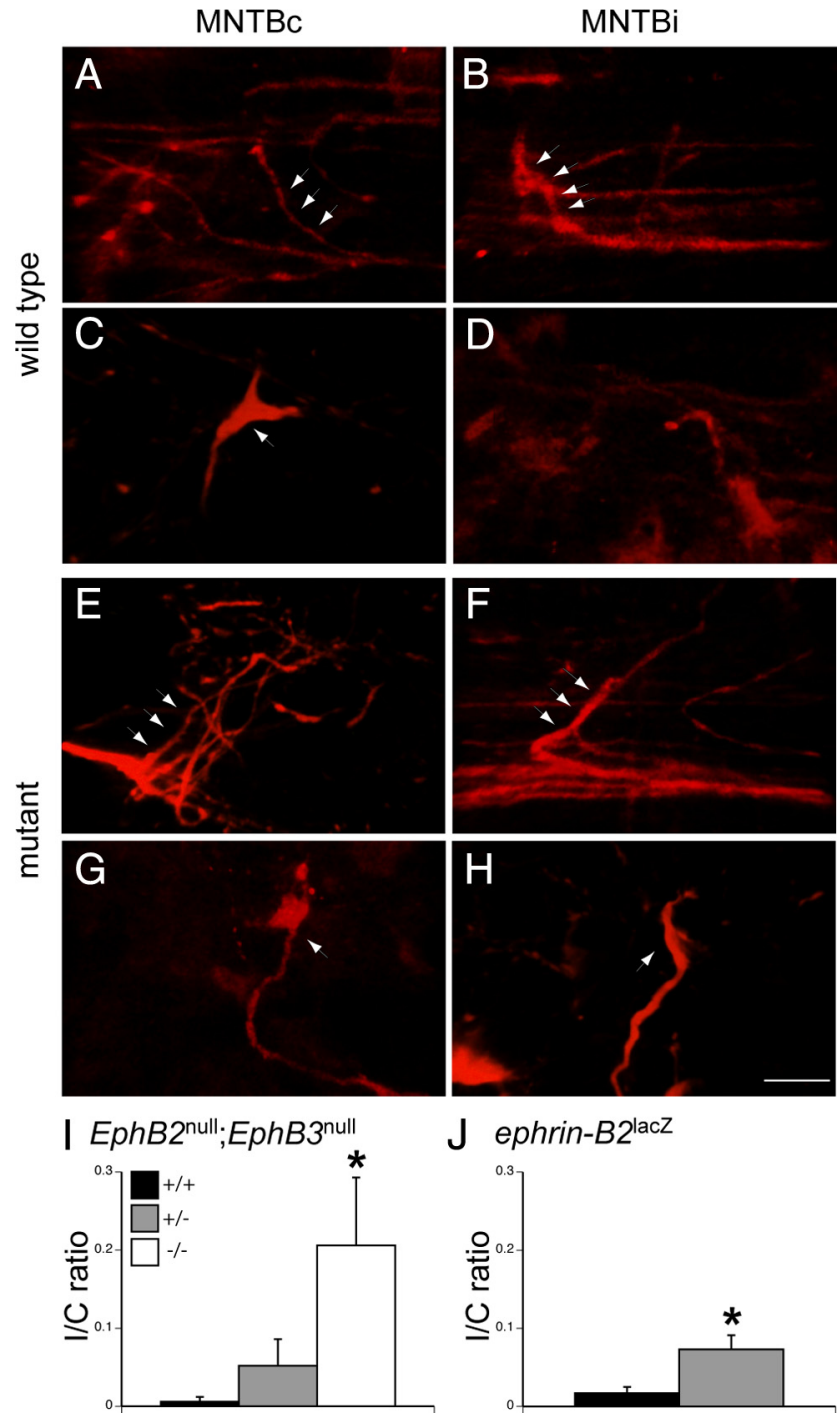

Figure 3. Aberrant projections develop at the same time as normal projections. These images were obtained from $P 3$ and P4 EphB2 wild-type and EphB2 null mice. Both mice have a null mutation in EphB3 that does not affect the VCN-MNTBc projection. In the wild type: $A$, RDA labeling in a $P 3$ wild-type mouse reveals small axon branches emerging from the ventral acoustic stria in MNTBC. $\boldsymbol{B}$, Similarly, small branches are seen in MNTBi. In $\boldsymbol{A}$ and $\boldsymbol{B}$, arrows indicate labeled axon branches. $C$, RDA labeling in a wild-type mouse at $P 4$ reveals an immature calyceal termination (arrow) in MNTBC. D, Branches in MNTBi do not have calyceal terminations. In the mutant: $\boldsymbol{E}$, RDA labeling in a P3 EphB2 null mutant reveals small branches emerging from the ventral acoustic stria in MNTBC. $\boldsymbol{F}$, Similarly, branches are seen in MNTBi. $\boldsymbol{G}$, RDA labeling of a P4 EphB2 null mutants reveals an immature calyceal termination in MNTBc. $\boldsymbol{H}$, In these mutants, abnormal projections with immature calyceal terminations are present in MNTBi. In $\boldsymbol{G}$ and $\boldsymbol{H}$, arrows indicate rudimentary calyceal terminations. $I, I / C$ ratios from the $E p h B 2^{\text {null }}$;EphB3 ${ }^{\text {null }}$ mouse line indicate that, even at this young age (P4-P5), there are significantly more aberrant projections (*) from VCN to MNTBi in EphB2 ${ }^{-/-} ;$EphB3 $^{-/-}$than EphB2 ${ }^{+/+} ; E$ EphB3 ${ }^{-/-}$or $E p h B 2^{+/-} ; E p h B 3^{-1-}$ mice. J, I/C ratios from the ephrin-B2 ${ }^{\text {lacZ }}$ mouse line indicate significantly more aberrant projections in ephrin-B2 $2^{\mathrm{lac} /+}$ than ephrin- $B 2^{+/+}$mice. ${ }^{*} p<0.05$. Scale bar (in $\boldsymbol{H}$ ): $\boldsymbol{A}-\boldsymbol{H}, 10 \mu \mathrm{m}$.

genotypes examined, $\quad E p h B 2^{+/+} ; E p h B 3^{-/-}, \quad E p h B 2^{\text {lacZl+}}$; $E p h B 3^{-1-}$, and EphB2 ${ }^{\text {lacZ/lacZ}} ; E p h B 3^{-1-}$, had normal projections from VCN terminating in MNTBc and few discernable projections to MNTBi. Figure 3, $F$ and $G$, shows labeling in an EphB2 $2^{\text {lacZ/lacZ }} ; E p h B 3^{-/-}$mouse. The I/C ratios for $E p h B 2^{+/+}$;

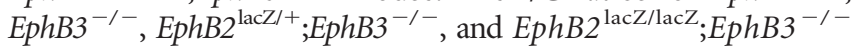
were $0.025 \pm 0.025(n=5), 0.010 \pm 0.006(n=9)$, and $0.000 \pm$ $0.000(n=3)$ (Fig. $2 H)$. These values were not significantly different from one another ( $p=0.568)$, suggesting that the intracellular domain of the EphB2 receptor and forward signaling through this region are not necessary for normal targeting of VCN axons to MNTB.

We then examined the ephrin-B2 ${ }^{\text {lacZ }}$ mouse line to further investigate the role of reverse signaling in strictly contralateral projections in the auditory brainstem (Fig. $2 I-K$ ). We found that, in ephrin- $B 2^{+/+}$mice, there were very few projections from VCN to MNTBi (data not shown), producing a very low I/C ratio $(0.046 \pm 0.010 ; n=16)$. In contrast, ephrin-B2 $2^{\text {lacZl+ }}$ mice had numerous calyces in MNTBi (Fig. $2 J$ ) in addition to the normal projections to $\mathrm{MNTBC}$ (Fig. $2 I$ ). The I/C ratio in ephrin-B2 ${ }^{\text {lacZ/+ }}$ mice $(0.138 \pm 0.028 ; n=12)$ was significantly higher than in ephrin-B2 $2^{+/+}$mice $(p<0.001)$ (Fig. $\left.2 K\right)$. The ephrin-B2 $2^{\text {lacZ/+ }}$ mice had I/C ratios similar to those obtained from $E p h B 2^{-/}$; $E p h B 3^{-1-}$ mice described above $(p=0.60)$. The results from these three transgenic mouse lines show that the absence of reverse signaling between EphB2 and ephrin-B2 is strongly associated with the robust appearance of aberrant ipsilateral calyces in MNTB.

\section{Aberrant and normal projections develop simultaneously}

We examined $E p h B 2^{\text {null }} ; E p h B 3^{\text {null }}$ and ephrin-B2 $2^{\text {lacZ }}$ mouse lines at earlier time points to determine whether the aberrant projections from VCN to MNTBi form concurrently with normal projections from VCN to MNTBc (Fig. 3). We used in vitro labeling to visualize projections from $\mathrm{VCN}$ at $\mathrm{P} 3-\mathrm{P} 5$, a time when calyces are first beginning to form in MNTB (Hoffpauir et al., 2006).

In $\mathrm{P} 3-\mathrm{P} 4$ wild-type animals (Fig. $3 A-D$ ), projections from VCN to MNTBc appeared as small branches emanating from the ventral acoustic stria (Fig. $3 A$ ) or as immature calyceal structures (Fig. 3C). These calyx-like terminations strongly colocalized with the presynaptic protein SV2 $(n=12)$ (supplemental Fig. 2, available at www.jneurosci.org as supplemental material). In MNTBi at this age, we observed collateral axon branches (Fig. $3 B, D$ ), but these ipsilateral branches did not have calyceal morphology and did not colocalize with SV2 (supplemental Fig. 2, available at www.jneurosci.org as supplemental material). At P5, we no longer observed small branches in MNTBc or MNTBi and only observed calyceal terminations in MNTBc (data not shown).

Similar to the results seen in wild-type mice, labeling of the VCN-MNTB pathway in both transgenic mouse lines at P3-P4 (Fig. $3 E-H$ ) revealed noncalyceal axonal branches emanating from the ventral acoustic stria in both MNTBc (Fig. 3E) and MNTBi (Fig. 3F). However, unlike the results in wild-type mice, labeling of the VCN-MNTB pathway revealed calyceal terminations in both MNTBc (Fig. 3G) and MNTBi (Fig. 3H). These rudimentary calyceal terminations were also present at $\mathrm{P} 5$ in both MNTBc and MNTBi (data not shown). EphB2 ${ }^{+/+} ; E p h B 3^{-/-}$ mice, like wild-type mice, had few if any aberrant calyceal terminations in MNTBi (I/C ratio of $0.006 \pm 0.006 ; n=11$ ) and significantly less than $E p h B 2^{-/} ; E p h B 3^{-1-}$ mice (Fig. 3I) (I/C ratio of $0.206 \pm 0.087 ; n=3 ; p<0.004)$. Likewise, in ephrin$B 2^{+/+}$mice, there were very few aberrant calyceal terminations in MNTBi (I/C ratio of $0.017 \pm 0.008 ; n=9)$, but there were significantly more projections to MNTBi in ephrin-B2 ${ }^{\mathrm{lacZ} /+}$ mice (Fig. $3 J)(\mathrm{I} / \mathrm{C}$ ratio $=0.073 \pm 0.018 ; n=11 ; p<0.022)$. Thus, at the first ages when calyces can be detected, both aberrant projections and normal projections arise at the same time in mutant $E p h B 2^{-1-} ; E p h B 3^{-1-}$ and ephrin-B2 $2^{\text {lacZ/+ }}$ mice. 

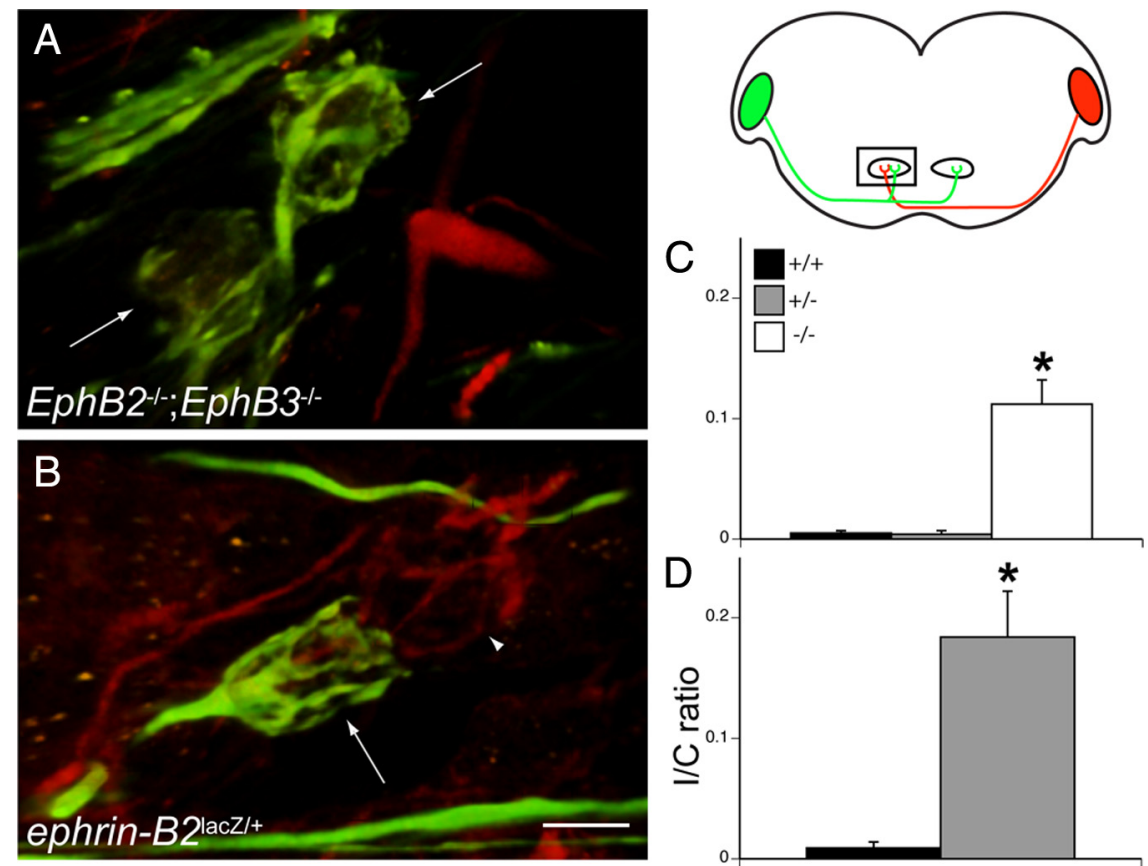

Figure 4. Aberrant projections persist after postnatal day 20. The schematic diagram on the right indicates orientation and dual dye labeling protocol. Alexa Fluor 488 dextran amine (green) was applied to one VCN, and RDA (red) was applied to the other VCN. In the diagram, the rectangle indicates the portion of the section in which labeling was evaluated, wherein green fluorescence indicates ipsilateral axons and red fluorescence indicates contralateral axons. A, Dual labeling of an older than P2O EphB2 ${ }^{-1-}$; $\mathrm{EphB3}^{-1-}$ mouse brainstem reveals mature but aberrant VCN-MNTBi projections. In this ipsilateral MNTB, there are two aberrant calyces (green). C, Quantification of aberrant calyces with $\mathrm{I} / \mathrm{C}$ ratios revealed that there are significantly more aberrant calyces in EphB2 ${ }^{-/-} ;$EphB3 $^{-/-}$mice (white bar) than EphB2 ${ }^{+/} ; \mathrm{EphB3}^{-/-}$or EphB2 ${ }^{+/-} ; E \mathrm{EphB3}{ }^{-/-}$mice (gray bar). B, Similarly, dual labeling of an older than $\mathrm{P} 20$ ephrin-B2 ${ }^{\mathrm{laCZ} /+}$ mouse brainstem reveals mature but aberrant VCN-MNTBi projections. In this example, an aberrant VCN-MNTBi calyx (green, arrow) is adjacent to a normal VCN-MNTBc calyx (red, arrowhead) $\boldsymbol{D}$. Quantification of aberrant calyces with $\mathrm{l} / \mathrm{C}$ ratios indicate that there are significantly more aberrant calyces in ephrin- $B 2^{\text {lacZ/+ }}$ (gray bar) than ephrin-B2 ${ }^{+/+}$(black bar) mice. ${ }^{*} p<0.05$. Scale bar: (in $\left.B\right) A, B, 10 \mu \mathrm{m}$.

\section{Aberrant projections persist after hearing onset}

We next determined whether aberrant projections from VCN to MNTBi persist or are eliminated later in development. We used bilateral dextran amine labeling of projections from VCN to the MNTB in acute brainstem slices from P20 and older, ages when hearing onset has occurred and when projections are considered mature. To visualize both normal and aberrant projections to a single MNTB, we injected one VCN with Alexa Fluor 488 dextran amine and the other VCN with RDA (Fig. 4). We found that, similar to results from earlier ages, EphB2 $2^{-/-} ; E p h B 3^{-/-}$(Fig. $4 A$ ) and ephrin-B2 ${ }^{\text {lacZ/+ (Fig. } 4 B \text { ) mice have significantly greater }}$ numbers of ipsilateral projections to MNTB than wild-type mice.

We quantified calyceal projections using the I/C ratio for both mouse lines at these older ages. Within the $E p h B 2^{\text {null }} ; E p h B^{\text {null }}$ line (Fig. 4C), EphB2 $2^{+/+} ; E p h B 3^{-/-}$mice lacked projections from VCN to MNTBi (I/C ratio of $0.005 \pm 0.002$; $n=17$ ); likewise, heterozygous $E p h B 2^{+/-} ; E p h B 3^{-/-}$mice had very few, if any, ipsilateral calyces (I/C ratio of $0.004 \pm 0.003 ; n=6$ ). However, numerous calyces were seen in MNTBi in $E p h B 2^{-1-}$; $E_{p h B 3}{ }^{-1-}$ mice (Fig. $4 A$ ) (I/C ratio of $0.112 \pm 0.020 ; n=3$ ), and the I/C ratio was significantly greater than $E p h B 2^{+/+}$; $\mathrm{EphB3}^{-1-}$ mice $(p<0.0049)$. We compared EphB2 $2^{-1-}$; $E p h B 3^{-1-}$ I/C ratios at this age with ratios from $\mathrm{P} 3-\mathrm{P} 5$ and $\mathrm{P} 10-$ $\mathrm{P} 14$ double mutants and found no significant difference $(p=$ 0.417 ), indicating that the aberrant projections from VCN to MNTBi persist at later ages.

We performed a similar dual labeling study in the ephrin$B 2^{\text {lacZ }}$ mouse line at P20 and older (Fig. $4 D$ ). Like EphB2 ${ }^{-{ }^{-}}$;
EphB3 ${ }^{-/-}$mice, ephrin-B2 $2^{\text {lacZ/+ }}$ mice retained their aberrant ipsilateral VCNMNTB projections. Figure $4 B$ shows a mature, ipsilateral calyx adjacent to contralateral axons and a normal calyx in an ephrin-B2 $2^{\text {lacZ/+ }}$ mouse. The mean I/C ratio in ephrin-B2 $2^{\text {lacZ/+ }}$ mice was $0.184 \pm$ $0.038(n=3)$, which was significantly greater than that obtained in ephrin$B 2^{+/+}$mice (I/C ratio of $0.009 \pm 0.005$; $n=3 ; p<0.049)$. Both EphB2 ${ }^{-1-}$; EphB3 ${ }^{-/-}$and ephrin-B2 $2^{\text {lacZ/+}}$ mice thus maintain their ipsilateral calyces at older ages.

In all of the mice examined using bilateral labeling at early and late ages, we found no cases in which an individual MNTB neuron received both ipsilateral and contralateral calyces, suggesting that mutant mice retain the ability to establish only a single VCN input per MNTB neuron. This observation suggests that ipsilateral VCN-MNTB projections in mutants thus replace the normal contralateral projection. An alternative possibility is that the ipsilateral projections may rescue MNTB neurons that would normally undergo cell death. If so, we would predict that mutants with bilateral VCN-MNTB projections would have a greater total number of MNTB neurons. To test this possibility, we compared the cell density and volume of thionin-stained MNTB in wild-type and ephrin-B2 $2^{\text {lacZ/+ }}$ mice. We found that ephrin-B2 $2^{\text {lacz/+ }}$ mice did not differ from wild-type mice in MNTB cell density $(p>0.1 ; n=3$ for each group) (supplemental Fig. 3, available at www.jneurosci. org as supplemental material). Moreover, the total volume of MNTB did not differ between ephrin-B2 $2^{\text {lacZ/+ }}$ mice and wild-type littermates $\left(p>0.1 ; n=6\right.$ wild-type mice and 4 ephrin-B2 $2^{\text {lacZl+ }}$ mice) (supplemental Fig. 3, available at www.jneurosci.org as supplemental material). Together, these data suggest that the number of MNTB neurons in these mutant mice is not different from wild-type mice. It is thus unlikely that MNTB neuron number is altered by the presence of ipsilateral VCN-MNTB projections in these mice.

To evaluate the origin of axons that form ipsilateral projections to MNTB, we made small injections to label individual axons in ephrin-B2 ${ }^{\text {lacZ/+ }}$ mice (supplemental Fig. 4, available at www.jneurosci.org as supplemental material). Of 10 cases in which individual axons that projected to MNTBi could be unambiguously resolved, seven could be followed back to parent branches that projected horizontally toward the midline, consistent with the possibility that ipsilateral calyces arise from branches of the normal, contralateral VCN-MNTB projection. In contrast, three axons were seen that projected only to ipsilateral MNTB, with no branch projecting toward the midline (supplemental Fig. 4, available at www.jneurosci.org as supplemental material).

\section{Ipsilateral calyces express presynaptic markers}

The calyceal terminations of ipsilateral VCN-MNTB projections appear morphologically very similar to the normal, contralateral 
termination. To assess the possibility that these aberrant ipsilateral calyces form synaptic contacts in MNTBi, we used synapsin I or SV2 immunofluorescence together with RDA axon labeling in animals P9 and older. RDA labeled ipsilateral calyces (Fig. 5A) in a P9 EphB2 $2^{-/-}$;EphB3 ${ }^{-/-}$ mouse colocalized with synapsin I immunofluorescence (Fig. 5B,C). Similarly, ipsilateral projections in a P26 ephrin$B 2^{\text {lacZ/+ }}$ mouse (Fig. 5D) colocalized with SV2 immunofluorescence (Fig. 5E, F). All of the labeled ipsilateral calyces examined ( $n=10$ mice) in both genotypes were immunopositive for presynaptic markers, similar to the normal synapses seen in MNTBc.

\section{Discussion}

We evaluated the role of EphB signaling in restricting the VCN-MNTB projection to the contralateral side of the brainstem. We found that, when calyces form in MNTB (P0-P4), EphB2 is expressed in VCN axons and ephrin-B2 expression in MNTB increases. Mice with mutations restricted to the intracellular domain of EphB2 showed no abnormality in VCN axon targeting. In contrast, EphB2 $2^{-/-} ; E p h B 3^{-/-}$ and ephrin-B2 $2^{\text {lacZ/+ }}$ mice had significant numbers of ipsilateral, calyceal VCNMNTB projections. In these mutants, VCN-MNTBi projections emerged during early stages of development and persisted through later ages. Some of these aberrant ipsilateral calyces arose from axons that projected only ipsilaterally, whereas others arose from collateral branches of axons that also projected contralaterally. Furthermore, these ipsilateral calyceal terminations expressed the synaptic markers SV2 and synapsin I, suggesting that they form functional connections.

Our results, summarized in Figure 6, suggest that ipsilateral calyceal projections are normally prevented by reverse signaling through ephrin-B2. Our expression data suggest that this reverse signaling is elicited in MNTB neurons by VCN axons that express EphB2. Together, our findings suggest that reverse signaling acts non-cell autonomously to prevent ipsilateral calyces from forming.

\section{Formation of contralateral}

\section{VCN-MNTB projections}

VCN axons normally grow through ipsilateral MNTB without forming connections and subsequently make contacts only with contralateral MNTB neurons. One possible explanation for this target specificity is that, when axons first encounter the ipsilateral MNTB, they are repelled, or lack sufficient attraction. Previous work has shown that VCN axons are strongly attracted to bar: (in $\boldsymbol{F}) \boldsymbol{A}-\boldsymbol{F}, 20 \mu \mathrm{m}$. projections.
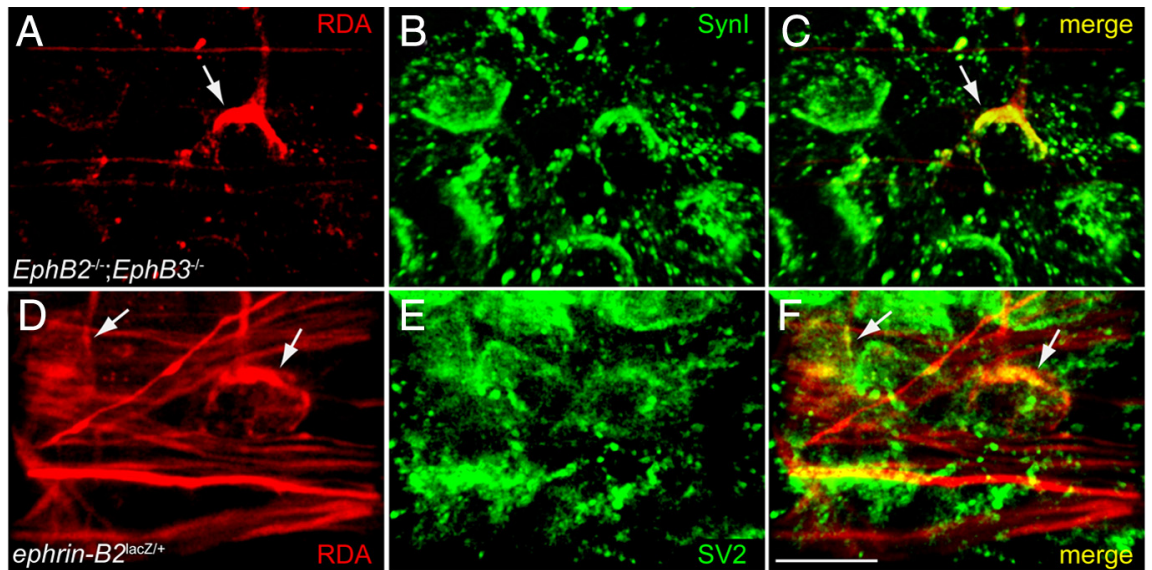

Figure 5. Aberrant ipsilateral calyces express presynaptic markers. $A$, In this mutant ipsilateral MNTB (P9 EphB2 ${ }^{-/-} ; E_{\text {EphB }}{ }^{-1-}$ ) RDA labeling reveals an aberrant calyx (arrow). $\boldsymbol{B}$, Expression of synapsin I (Synl) in the same section as in $\boldsymbol{A}$. C, Merge of $\boldsymbol{A}$ and $\boldsymbol{B}$ indicates that the RDA-labeled aberrant calyx is also positive for synapsin I (yellow). $\boldsymbol{D}$, In a different mutant ipsilateral MNTB (P26 ephrin-B2 ${ }^{\mathrm{lac} Z /+}$ ), RDA labeling reveals axons (red) and two aberrant calyces (arrows). E, SV2 immunofluorescence in the same section as in $\boldsymbol{D}$. $\boldsymbol{F}$, Merge of $\boldsymbol{D}$ and $\boldsymbol{E}$ indicates that the RDA-labeled calyces (arrows) are also positive for SV2 (yellow). Scale

\section{GENOTYPE A Wild type B EphB2 $\%$ C EphB2 laczlacz D ephrin-B2 lacZ/+}

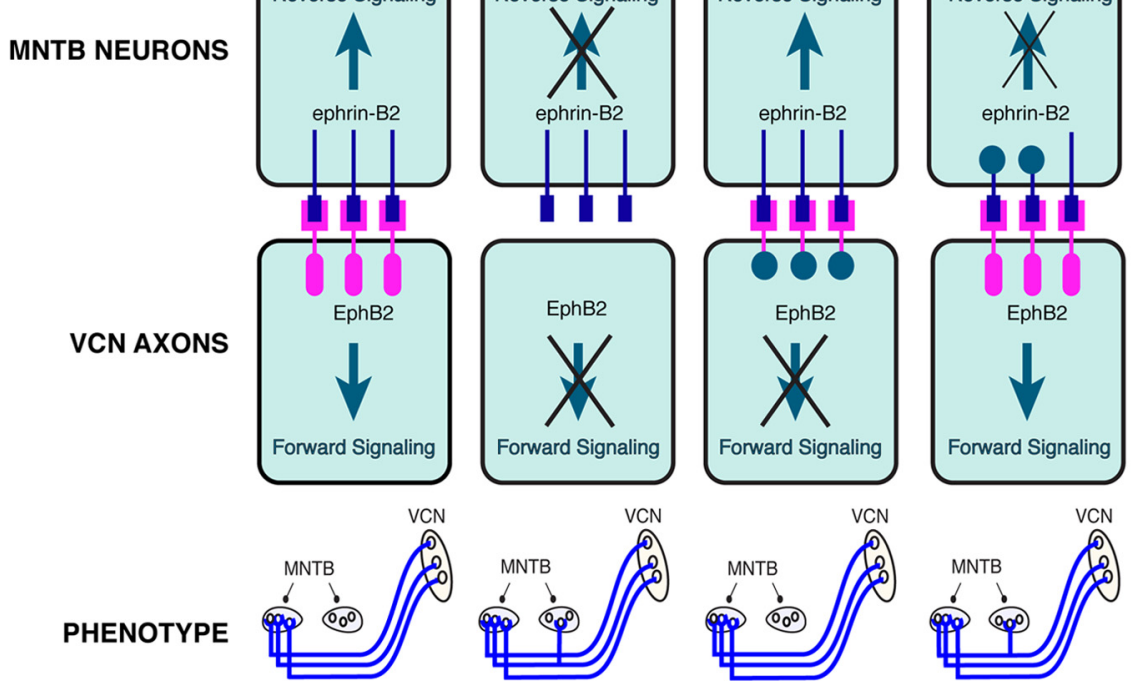

Figure 6. Summary of results suggesting that reverse signaling through ephrin-B2 in MNTB neurons prevents the formation of ipsilateral calyces. Genotype is indicated across the top row, and phenotype is indicated across the bottom row. $A$, In wild-type mice, signaling occurs bidirectionally, as both the receptor (pink) and the ligand (blue) are fully expressed. These mice have a normal phenotype (bottom), in which VCN projects to contralateral, but not ipsilateral, MNTB. $B$, In EphB2 ${ }^{-1-}$ mice, a null mutation eliminates the EphB2 protein entirely, so signaling does not occur in either forward or reverse direction. Our data indicate that these mice have a significant number of abnormal ipsilateral VCN-MNTB projections. C, EphB2 ${ }^{\text {lacz/lacz }}$ mice have $\beta$-galactosidase replacing the intracellular portion of the EphB2 receptor. Thus, they cannot signal in the forward direction, but reverse signaling functions normally. These mice have normal, contralateral VCN-MNTB projections. D, Ephrin-B2 ${ }^{\text {lacz/+ }}$ mice have intact forward signaling but reverse signaling through ephrin-B2 is reduced. These mice have abnormal ipsilateral VCN-MNTB

the midline during early brainstem development (Poe and Brunso-Bechtold, 1998). Specifically, netrin-1 is expressed at the midline of the brainstem during the initial growth of VCN axons, which express the netrin receptor DCC (deleted in colorectal cancer); mutations in either of these genes results in a failure of the ventral acoustic stria to form (Howell et al., 2007). As in the spinal cord (Stein and Tessier-Lavigne, 2001), VCN axon attrac- 
tion to netrin might diminish after axons reach the midline, permitting axon growth toward contralateral MNTB.

In our studies, all genotypes had substantial contralateral VCNMNTB projections. EphB2 and ephrin-B2 are thus not necessary for growth across the midline or for formation of contralateral calyces. Instead, mutations in EphB2 and ephrin-B2 resulted in a significant number of projections from $\mathrm{VCN}$ to ipsilateral MNTB. Our results suggest that, during normal development, these molecules prevent the formation of ipsilateral VCNMNTB projections.

\section{Formation of ipsilateral VCN-MNTB projections in mutant mice}

We show that ephrin-B2 is expressed in MNTB only after P0, when VCN axons have grown past MNTBi, crossed the midline, and arrived at MNTBc (Kil et al., 1995; Hoffpauir et al., 2006). EphB2-ephrin-B2 signaling could commence at this time during the initial contacts between VCN growth cones and MNTB cells. This interaction might normally result in an environment that inhibits formation of ipsilateral contacts. In mutants, reduced inhibition could promote the induction or maintenance of ipsilateral sprouts. Additionally, it could alter the likelihood that existing ipsilateral branches form calyceal terminations in MNTB.

EphB signaling promotes synapse maturation (Henkemeyer et al., 2003; Kayser et al., 2006, 2008; Lim et al., 2008; McClelland et al., 2009) and could thus influence the ability of VCN axon branches in ipsilateral MNTB to make synaptic contacts. However, our data show that a decrease in signaling enhances formation of synaptic contacts between VCN axon branches and ipsilateral MNTB, contradicting EphB functions in other systems. Moreover, mutant mice appear to have normal contralateral terminations. It is thus likely that mutant phenotypes arise instead from increased ipsilateral axon branching or increased stability of these ipsilateral branches. In support of this possibility, several studies have demonstrated that EphB signaling influences axon branching, and this signaling can promote either branch growth (Hindges et al., 2002) or retraction (Xu and Henkemeyer, 2009).

\section{Origins of ipsilateral projections}

Ipsilateral calyceal projections have been described previously under two other circumstances. In the first, unilateral cochlear deafferentation induces sprouting of the intact $\mathrm{VCN}$ axons to form ipsilateral calyces (Kitzes et al., 1995; Russell and Moore, 1995; Hsieh et al., 2007). These projections can be induced at later postnatal ages when the branches observed at P3-P4 are no longer present in ipsilateral MNTB (Hsieh and Cramer, 2006). In the second, null mutations of Robo3 cause VCN axons to grow only to the ipsilateral MNTB and form calyceal terminations without reaching the midline (Renier et al., 2010). These results suggest that ipsilateral calyceal projections may result from branches of normal, contralateral projections or as direct exclusive projections from VCN to ipsilateral MNTB.

Both types of projection in EphB2 or ephrin-B2 mutants could potentially underlie our finding that reverse signaling through ephrin-B2 is needed to prevent the formation of ipsilateral VCN-MNTB projections. Our observations of single axons suggest that both types of projection occur in mice with mutations in EphB2 or ephrin-B2. Strictly ipsilateral projections might arise in mutants if axons experience increased attraction during their initial growth through MNTBi. An interesting possibility that may account for our diverse observations in single axons is that mutant VCN-MNTBi axons may extend or retract their contralateral branches during the postnatal period. Additional studies examining how these axons change over time are thus needed to characterize fully the source of ipsilateral VCN-MNTB projections in these mutants.

\section{Effects of EphB2-ephrin-B2 signaling}

A role for reverse signaling in the normal targeting of $\mathrm{VCN}-$ MNTB axons is supported by the observation of aberrant ipsilateral calyces in ephrin-B2 $2^{\text {lacZ/+ }}$ mice, in which reverse signaling is reduced but forward signaling is normal. The number of aberrant, ipsilateral projections in these mice was similar to that seen in EphB2 $2^{-1-} ; E p h B 3^{-1-}$ mutants. Moreover, the EphB2 ${ }^{\text {lacZ }} \mathrm{mu}-$ tation, which permits reverse but not forward signaling, has no effect. These data, together with expression patterns, suggest that interactions between VCN axons and MNTB cells normally permit reverse signaling in the MNTB target cell, and this reverse signaling results in an environment that non-cell autonomously limits the formation of ipsilateral calyces (Fig. 6). In the absence of reverse signaling, ipsilateral VCN axon branches would encounter a permissive environment in MNTB.

Our results suggest that normal signaling between VCN axons and MNTB inhibits the formation of ipsilateral calyces. This finding is consistent with findings after unilateral deafferentation (Kitzes et al., 1995; Russell and Moore, 1995; Hsieh and Cramer, 2006; Hsieh et al., 2007), in which VCN-MNTB projections might be attracted toward MNTB cells after inhibitory signals induced by intact projections are removed. Interestingly, in mice lacking the Eph receptor EphA4, which binds to ephrin-B2 (Gale et al., 1996), lesion-induced ipsilateral projections are more numerous (Hsieh et al., 2007), consistent with the idea that Eph protein signaling limits ipsilateral projections.

There are several possible ways in which EphB2-ephrin-B2 binding could alter signals affecting formation of ipsilateral connections. EphB2-ephrin-B2 binding is part of a complex set of interactions mediated by the large family of Eph proteins. Relative levels of Eph signaling are significant determinants of axon trajectories for EphA proteins (Brown et al., 2000; Reber et al., 2004). Moreover, the function of Eph proteins as attractants or repellants varies with concentration and may result from concentration-dependent differences in oligomerization (Stein et al., 1998; Huynh-Do et al., 1999; Hansen et al., 2004). Mutations in EphB2 or ephrin-B2 could thus shift the balance of repulsion and attraction in the VCN-MNTB pathway so that a significant fraction of VCN neurons project to MNTBi and remain.

An alternative possibility is that axons that contact MNTB cells might, through reverse signaling, result in production of increased activity of repulsive molecules, through either posttranslational modifications or altered gene expression. Mutations that impair reverse signaling would reduce the level of repulsion in MNTB and permit growth of ipsilateral projections. The characterization of proteins whose activity is modified by reverse ephrin-B2 signaling in MNTB, and the effects of these proteins on ipsilateral VCN branches, remain to be determined.

\section{Selective effects on ipsilateral VCN-MNTB projections}

The robust effects of EphB2 and ephrin-B2 mutations raise the question of how these proteins might normally act to selectively prevent these ipsilateral VCN-MNTB projections. An interesting possibility is that ipsilateral branches might express EphB2 in different amounts than contralateral branches. In support of this possibility is the observation that interstitial branches of avian 
retinal ganglion cells are selectively influenced by ephrin-B1, possibly as a result of selective subcellular targeting of EphB receptors (or their mRNA) to these branches (McLaughlin et al., 2003). Indeed, Eph protein synthesis has been demonstrated in axons and can result in expression in focal regions within axons (Brittis et al., 2002).

Ipsilateral VCN axon branches receive guidance cues that are distinct from those encountered by contralateral axon segments, primarily because they do not encounter the midline. Moreover, normally occurring ipsilateral branches form after the contralateral branches have reached the contralateral superior olivary complex (Howell et al., 2007). Thus, exposure to distinct environments would enable distinct responses to cues that determine the competence of axon branches to form terminations in MNTB.

\section{References}

Boudreau JC, Tsuchitani C (1968) Binaural interaction in the cat superior olive S segment. J Neurophysiol 31:442-454.

Brittis PA, Lu Q, Flanagan JG (2002) Axonal protein synthesis provides a mechanism for localized regulation at an intermediate target. Cell 110:223-235.

Brown A, Yates PA, Burrola P, Ortuño D, Vaidya A, Jessell TM, Pfaff SL, O'Leary DD, Lemke G (2000) Topographic mapping from the retina to the midbrain is controlled by relative but not absolute levels of EphA receptor signaling. Cell 102:77-88.

Brückner K, Pasquale EB, Klein R (1997) Tyrosine phosphorylation of transmembrane ligands for Eph receptors. Science 275:1640-1643.

Cant NB, Casseday JH (1986) Projections from the anteroventral cochlear nucleus to the lateral and medial superior olivary nuclei. J Comp Neurol 247:457-476.

Casseday JH, Neff WD (1973) Localization of pure tones. J Acoust Soc Am 54:365-372.

Cowan CA, Yokoyama N, Bianchi LM, Henkemeyer M, Fritzsch B (2000) EphB2 guides axons at the midline and is necessary for normal vestibular function. Neuron 26:417-430.

Cramer KS (2005) Eph proteins and the assembly of auditory circuits. Hear Res 206:42-51.

Cramer KS, Cerretti DP, Siddiqui SA (2006) EphB2 regulates axonal growth at the midline in the developing auditory brainstem. Dev Biol 295:76-89.

Davy A, Soriano P (2005) Ephrin signaling in vivo: look both ways. Dev Dyn 232:1-10.

Dravis C, Yokoyama N, Chumley MJ, Cowan CA, Silvany RE, Shay J, Baker LA, Henkemeyer M (2004) Bidirectional signaling mediated by ephrin-B2 and EphB2 controls urorectal development. Dev Biol 271:272-290.

Egea J, Klein R (2007) Bidirectional Eph-ephrin signaling during axon guidance. Trends Cell Biol 17:230-238.

Flanagan JG (2006) Neural map specification by gradients. Curr Opin Neurobiol 16:59-66.

Ford MC, Grothe B, Klug A (2009) Fenestration of the calyx of Held occurs sequentially along the tonotopic axis, is influenced by afferent activity, and facilitates glutamate clearance. J Comp Neurol 514:92-106.

Gale NW, Holland SJ, Valenzuela DM, Flenniken A, Pan L, Ryan TE, Henkemeyer M, Strebhardt K, Hirai H, Wilkinson DG, Pawson T, Davis S, Yancopoulos GD (1996) Eph receptors and ligands comprise two major specificity subclasses and are reciprocally compartmentalized during embryogenesis. Neuron 17:9-19.

Glendenning KK, Baker BN, Hutson KA, Masterton RB (1992) Acoustic chiasm V: inhibition and excitation in the ipsilateral and contralateral projections of LSO. J Comp Neurol 319:100-122.

Hansen MJ, Dallal GE, Flanagan JG (2004) Retinal axon response to ephrin-as shows a graded, concentration-dependent transition from growth promotion to inhibition. Neuron 42:717-730.

Henkemeyer M, Orioli D, Henderson JT, Saxton TM, Roder J, Pawson T, Klein R (1996) Nuk controls pathfinding of commissural axons in the mammalian central nervous system. Cell 86:35-46.

Henkemeyer M, Itkis OS, Ngo M, Hickmott PW, Ethell IM (2003) Multiple EphB receptor tyrosine kinases shape dendritic spines in the hippocampus. J Cell Biol 163:1313-1326.
Himanen JP, Chumley MJ, Lackmann M, Li C, Barton WA, Jeffrey PD, Vearing C, Geleick D, Feldheim DA, Boyd AW, Henkemeyer M, Nikolov DB (2004) Repelling class discrimination: ephrin-A5 binds to and activates EphB2 receptor signaling. Nat Neurosci 7:501-509.

Hindges R, McLaughlin T, Genoud N, Henkemeyer M, O’Leary DD (2002) EphB forward signaling controls directional branch extension and arborization required for dorsal-ventral retinotopic mapping. Neuron 35:475-487.

Hoffpauir BK, Grimes JL, Mathers PH, Spirou GA (2006) Synaptogenesis of the calyx of Held: rapid onset of function and one-to-one morphological innervation. J Neurosci 26:5511-5523.

Hoffpauir BK, Marrs GS, Mathers PH, Spirou GA (2009) Does the brain connect before the periphery can direct? A comparison of three sensory systems in mice. Brain Res 1277:115-129.

Holland SJ, Gale NW, Mbamalu G, Yancopoulos GD, Henkemeyer M, Pawson T (1996) Bidirectional signalling through the EPH-family receptor Nuk and its transmembrane ligands. Nature 383:722-725.

Howell DM, Morgan WJ, Jarjour AA, Spirou GA, Berrebi AS, Kennedy TE, Mathers PH (2007) Molecular guidance cues necessary for axon pathfinding from the ventral cochlear nucleus. J Comp Neurol 504:533-549.

Hsieh CY, Cramer KS (2006) Deafferentation induces novel axonal projections in the auditory brainstem after hearing onset. J Comp Neurol 497:589-599.

Hsieh CY, Hong CT, Cramer KS (2007) Deletion of EphA4 enhances deafferentation-induced ipsilateral sprouting in auditory brainstem projections. J Comp Neurol 504:508-518.

Huynh-Do U, Stein E, Lane AA, Liu H, Cerretti DP, Daniel TO (1999) Surface densities of ephrin-B1 determine EphB1-coupled activation of cell attachment through alphavbeta3 and alpha5betal integrins. EMBO J 18:2165-2173.

Irvine DRF (1986) A review of the structure and function of auditory brainstem processing mechanisms. In: Sensory physiology (Ottoson D, ed), pp 1-279. Berlin: Springer.

Kandler K, Friauf E (1993) Pre- and postnatal development of efferent connections of the cochlear nucleus in the rat. J Comp Neurol 328:161-184.

Kayser MS, McClelland AC, Hughes EG, Dalva MB (2006) Intracellular and trans-synaptic regulation of glutamatergic synaptogenesis by EphB receptors. J Neurosci 26:12152-12164.

Kayser MS, Nolt MJ, Dalva MB (2008) EphB receptors couple dendritic filopodia motility to synapse formation. Neuron 59:56-69.

Kil J, Kageyama GH, Semple MN, Kitzes LM (1995) Development of ventral cochlear nucleus projections to the superior olivary complex in gerbil. J Comp Neurol 353:317-340.

Kitzes LM, Kageyama GH, Semple MN, Kil J (1995) Development of ectopic projections from the ventral cochlear nucleus to the superior olivary complex induced by neonatal ablation of the contralateral cochlea. J Comp Neurol 353:341-363.

Klein R (2009) Bidirectional modulation of synaptic functions by Eph/ephrin signaling. Nat Neurosci 12:15-20.

Lai KO, Ip NY (2009) Synapse development and plasticity: roles of ephrin/ Eph receptor signaling. Curr Opin Neurobiol 19:275-283.

Lim BK, Matsuda N, Poo MM (2008) Ephrin-B reverse signaling promotes structural and functional synaptic maturation in vivo. Nat Neurosci 11:160-169.

McClelland AC, Sheffler-Collins SI, Kayser MS, Dalva MB (2009) Ephrin-B1 and ephrin-B2 mediate EphB-dependent presynaptic development via syntenin-1. Proc Natl Acad Sci U S A 106:20487-20492.

McLaughlin T, O'Leary DD (2005) Molecular gradients and development of retinotopic maps. Annu Rev Neurosci 28:327-355.

McLaughlin T, Hindges R, Yates PA, O'Leary DD (2003) Bifunctional action of ephrin-B1 as a repellent and attractant to control bidirectional branch extension in dorsal-ventral retinotopic mapping. Development 130:2407-2418.

Miko IJ, Nakamura PA, Henkemeyer M, Cramer KS (2007) Auditory brainstem neural activation patterns are altered in EphA4- and ephrin-B2deficient mice. J Comp Neurol 505:669-681.

Miko IJ, Henkemeyer M, Cramer KS (2008) Auditory brainstem responses are impaired in EphA4 and ephrin-B2 deficient mice. Hear Res 235:39-46.

Nguyen QT, Callamaras N, Hsieh C, Parker I (2001) Construction of a twophoton microscope for video-rate $\mathrm{Ca}^{2+}$ imaging. Cell Calcium 30:383-393. 
Pasquale EB (2008) Eph-ephrin bidirectional signaling in physiology and disease. Cell 133:38-52.

Poe BH, Brunso-Bechtold JK (1998) Directed outgrowth from a subset of cochlear nucleus fibers in a collagen-gel matrix. Brain Res Dev Brain Res 105:153-157.

Reber M, Burrola P, Lemke G (2004) A relative signalling model for the formation of a topographic neural map. Nature 431:847-853.

Renier N, Schonewille M, Giraudet F, Badura A, Tessier-Lavigne M, Avan P, De Zeeuw CI, Chédotal A (2010) Genetic dissection of the function of hindbrain axonal commissures. PLoS Biol 8:e1000325.

Rodríguez-Contreras A, van Hoeve JS, Habets RL, Locher H, Borst JG (2008) Dynamic development of the calyx of Held synapse. Proc Natl Acad Sci U S A 105:5603-5608.

Russell FA, Moore DR (1995) Afferent reorganisation within the superior olivary complex of the gerbil: development and induction by neonatal, unilateral cochlear removal. J Comp Neurol 352:607-625.

Sanes DH (1990) An in vitro analysis of sound localization mechanisms in the gerbil lateral superior olive. J Neurosci 10:3494-3506.

Sonntag M, Englitz B, Kopp-Scheinpflug C, Rübsamen R (2009) Early postnatal development of spontaneous and acoustically evoked discharge ac- tivity of principal cells of the medial nucleus of the trapezoid body: an in vivo study in mice. J Neurosci 29:9510-9520.

Stein E, Tessier-Lavigne M (2001) Hierarchical organization of guidance receptors: silencing of netrin attraction by slit through a Robo/DCC receptor complex. Science 291:1928-1938.

Stein E, Lane AA, Cerretti DP, Schoecklmann HO, Schroff AD, Van Etten RL, Daniel TO (1998) Eph receptors discriminate specific ligand oligomers to determine alternative signaling complexes, attachment, and assembly responses. Genes Dev 12:667-678.

Stutzmann GE, Parker I (2005) Dynamic multiphoton imaging: a live view from cells to systems. Physiology (Bethesda) 20:15-21.

Stutzmann GE, LaFerla FM, Parker I (2003) $\mathrm{Ca}^{2+}$ signaling in mouse cortical neurons studied by two-photon imaging and photoreleased inositol triphosphate. J Neurosci 23:758-765.

Tollin DJ (2003) The lateral superior olive: a functional role in sound source localization. Neuroscientist 9:127-143.

Wilkinson DG (2001) Multiple roles of EPH receptors and ephrins in neural development. Nat Rev Neurosci 2:155-164.

Xu NJ, Henkemeyer M (2009) Ephrin-B3 reverse signaling through Grb4 and cytoskeletal regulators mediates axon pruning. Nat Neurosci 12:268276. 